Junichi Toyota*

https://doi.org/10.18485/analiff.2018.30.1.11

Graduate School

81 '373.612.2

of Literature and Human Sciences

Originalni naučni rad

Osaka City University

Primljen: 12.06 .2018 .

Prihvaćen: 22.09.2018.

\title{
CULTURE AND LIVING ENVIRONMENT IN LANGUAGE: A CASE OF POSSIBLE VARIATIONS IN METAPHOR ${ }^{1}$
}

\begin{abstract}
This paper examines a possibility of metaphors of cognition using sensory verbs based on touch, i.e. somatosensation. Among the five basic perceptions, a common source for metaphor concerning knowledge and understanding is vision, commonly known as KNOWLEDGE IS VISION, i.e. I see your point, meaning 'I understand your point'. Another type of sensation used in this metaphor is hearing, often found in languages spoken in certain regions, such as Australia, Papua New Guinea, East Africa, etc. The use of hearing is a result of religious influence, in a sense that only religious people are able to 'see' everything, and the use of vision is reserved to certain religiously gifted people and common people resort to other sources. The case of somatosensation may not involve cultural influence such as religion, but topography or climate may be of importance in creating this type of metaphor. A case in question is Finnish, which has developed a verb of cognition based on a word käsi 'hand'.
\end{abstract}

Key words: metaphor of cognition, somatosentation, topography, climate, body parts

\section{Introduction}

Much of research in linguistics in the past couple of decades has been dedicated to finding universal features. However, as typological studies have gained in popularity and diversities in structure and usage against universal emerged. These diversities are not merely a variation in forms and meaning, but can be a reflection of culture and topography, i.e. how

* toyotaj.lit.osaka.cu@gmail.com

1 The abbreviations used in this paper are as follows: COP = copula; ERG = ergative; $\mathrm{LOC}=$ locative; $\mathrm{NEG}=$ negative; $\mathrm{NOMZR}=$ nominaliser; PRS = present; $\mathrm{PRT}=$ particle; $\mathrm{PST}=$ past; $\mathrm{SG}=$ singular; $\mathrm{VN}=$ verbal noun. 
people have seen the world and conceptualise it. This idea is not totally new, but it has not been studied in the area of metaphor. Metaphor often assumes that its source domain is influenced by speakers' experience or cognitive frame, but experience can be altered according to living environment. This may be beyond linguistic study, but with interdisciplinary approaches, one may be able to investigate the relationship between how we express ourselves through language and our living environments. Following this line of research, we argue in this paper that metaphor can also be affected by, broadly speaking, topography and climate. Metaphors relating to vision are studied, i.e. KNOWLEDGE IS VISION, as exemplified in English I see your point. This conceptual metaphor is considered universal, but there are variations in less studied languages, involving hearing and smell as a source of perception. A particular case in question here is a use of touch, i.e. somatosensation. In some languages, it seems that the type KNOWLEDGE IS TOUCH seems to be possible, and this is analysed in terms of speakers' living environment.

The organisation of this paper is as follows: the relationship between metaphor and culture cum cognition is shown to highlight that there may be exceptional cases for what is commonly recognised as conceptual metaphor. A particular example is metaphor concerning time, particularly considering a case of Aymara. Then metaphors concerning vision, i.e. KNOWLEDGE IS VISION, are discussed, presenting various non-standard cases from languages from Australia and Africa. Finally, somatosensation in metaphor is examined in relation to speakers' living environment, including topography and climate.

\section{Metaphor, culture and cognition: a case of expression of time}

Let us look at metaphors expressing time. Time is often considered as motion in conceptual metaphor, i.e. TIME PASSING IS MOTION according to Lakoff (1993). In a broad sense, time and space have been considered closely related, and even when there is no motion, plotting a time as a static point in the flow of time can be possible. Consider a case from Irish in (1). A sequence of events is plotted one after another, and the temporal sequence is considered in a spatial sense (i.e. front and rear), and this 
spatial relationship is expressed with a preposition tar eis 'after', yielding a reading 'I am in a state of being after an event of finishing a work.' A number of languages use this type of space-based expressions to refer to time.

\section{(1) Tá mé tar eis mo chuig óbair a chrioughnú COP I after my piece work PRT finish.VN 'I have finished my work.' (lit. 'I am after finishing my work.')}

Núñes and Sweetser (2006) further divide it into two types, i.e. TIME PASSING IS MOTION OF AN OBJECT (moving time) and TIME PASSING IS MOTION OVER A LANDSCAPE (moving Ego). The variation is made according to whether time is conceived as spatial objects or static objects. Núñes and Sweetser (ibid.: 406) describes the difference as follows, along with schematic representation in Figure 1.

The special case TIME PASSING IS MOTION OF AN OBJECT metaphor is depicted in (a), where times are conceived as spatial objects moving, relative to a static canonical observer, from front (future times) to back (past times). In this case, the observer is the deictic center. The other special case of the metaphor, TIME PASSING IS MOTION OVER A LANDSCAPE, is illustrated in (b), where the observer moves relative to static objects conceived as times. The deictic center in this case is a static object in the landscape.

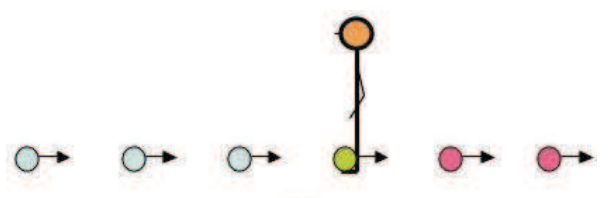

(a)

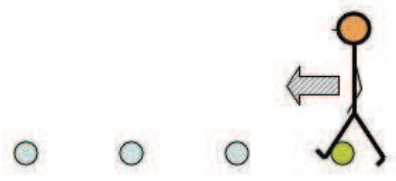

(b)

Figure 1. Moving time (a) and moving ego (b) (Núñes and Sweetser 2006: 406) 
This difference is borne out of research in Aymara, where the conceptualisation of time based on physical space is reversed from that of common Indo-European languages, i.e. the front is considered as past and the rear, future in Aymara. This is also shown in gesture, where waving forwards refers to past, and backwards, future. Aymara is known for exhibiting this type of conceptualisation of time, but it can be found in other languages, such as Tuvan (Turkic, Klein 1987), Maori (Austronesian, Thornton 1987), Malagasy (Austronesian, Dhal 1995) and Brazilian sign language (p.c. Lorraine Leeson). This can be also seen in grammaticalisation of time-reference words based on body parts or spatial expressions with body as a deictic centre. Heine and Kuteva (2002) presents a number of examples, as shown in (2) to (4). In English, for instance, a body part back became a temporal adverb 'earlier'. Other examples are demonstrated in (2). Likewise, the front part of the body refers to futurity, as shown in (3). A case of Aymara shows the opposite pattern, and the front part became past reference, and the backside of the body, future reference, as demonstrated in (4).

Front $>$ future

(2) Thai lay 'back' >lay-càag 'after' (lit. 'back from'); Icelandic bak 'back' > baki 'behind, after'; English back (N) > 'earlier'; Nanay (Tungustic) xamasi 'back' > 'ago'; Estonian tagasi 'back'> 'ago'.

Back $>$ past

(3) Shona (Bantu) mberi 'front' > 'ahead'; Moré (Niger-Congo) béoghé 'be in front' > béogho 'tomorrow, the following day'.

Back > future; front $>$ past (Núñes and Sweetser 2006: 402)

(4) Aymara nayra 'eye/front/sight' for past, qhipa 'back/behind' for future

The difference here lies on how visualisation plays a role in culture. In case of Aymara, the past events are experienced by speakers, in a sense of 'they have seen these events.' Future events, along this line of conceptualisation, cannot be seen and therefore, future is considered to be located at the back of their head. It is often the case that in these cultures, shamanism and different forms of native religions play an important role in their daily life, and they even affect the form of languages in some occasions. 


\section{Vision and cognition}

In a number of languages, vision is often used as a source domain for metaphor of cognition, e.g. English I see your point, meaning 'I understand your point'. 'Seeing is believing' seems to hold true in this case. This has a long history, as the vocabulary related to comprehension and knowledge in modern languages can be traced back to vision-related meanings. For instance, Proto-Germanic wáit'I know' is derived from Proto-Indo-European *weyd- 'see'. Originally, Proto-Germanic wáit was a perfective form of a verb of vision. The aspectual meaning 'I have completed seeing' was not shifted to the past tense 'I saw/have seen' as commonly found in various languages, but rather to 'I know'. This line of development suggests that what was visually experienced was considered as knowledge. In modern Germanic languages, the residues of this line of development can be seen in German wissen 'know' or English wise and wit. Outside of the Germanic languages, Irish fios 'knowledge' is also derived from the same source.

By looking at the case of Germanic languages, the link between vision and cognition seems to be very strong, but this is not universal. For instance, in spite of the presence of the metaphor, MacArthuer et al. (2015) points out that the frequency can vary in each language, and its use is very frequent in English, but not so in Spanish. In addition, typologically there are variations concerning metaphors referring to knowledge, e.g. Evans and Wilkins (2000) reports a case of knowledge is audition in Australian languages, and Thanassoula (2016) presents a case of knowledge is olfaction in a Bantu language, Lussessee. For instance, an Australian language Pitjantjatjara has a verb kulini'hear', as exemplified in (5a), and it is highly polysemous. Among various senses, this verb can be used as a verb of cognition, as exemplified in (5b). This is not what is expected in, for instance, Indo-European languages, and what is unique in these languages is that verbs of hearing seem to be the prime source for semantic extensions.

Pitjantjatjara (Australian, Evans and Wilkinson 2000: 563, 564)

a. Ngayulu anangu-ngku wangkanytjala kulinu
I people-ERG talk.NOMZR.LOC hear.PST
'I hear people talking.'
butuka/ compyter ngayulu putu kulini
car computer I in.vain understand.PRS
'I don't understand cars/computers.'


As for Lussessee, the use of a verb of olfaction for cognition, i.e. 'I smell your point', is reserved to religious people. As shown in Figure 2, a verb of cognition -húlirà 'feel/hear' is used by lay people, and a verb of religious register -núuka 'smell good' is reserved to shamans. This practice stems from their local belief where the deceased communicate with their descendants through smell, and only the religious people can interpret what each smell means or signifies. Note that the religious people can also use vision in Lussessee, restricting the lay people only to the verb of hearing.

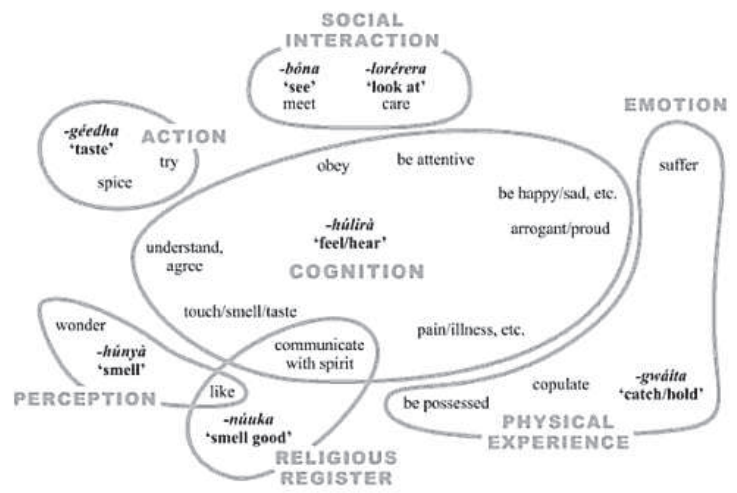

Figure. 2 Lussesse (Bantu) perception (Thanassoula 2013: 255)

Viberg (1984: 136) presents a hierarchical order of perception, as in Figure 3. This hierarchy shows that vision is the prime perception in humans. Furthermore, as shown in Figure 4, Viberg (1984) schematically represents a relationship among five basic perceptions. In this figure, vision plays a central role in meaning extension. This is what can be commonly found in the world languages. However, Evans and Wilkinson (2000) provide a schematic representation based on the Australian languages, as in Figure 5, and it is clear that the verb of hearing plays a central role among these languages, and the dotted line here shows a dubious case and this extension is dependent on how one interprets data and thus they leave it open for interpretation. Therefore, the importance of vision may not be universally so significant, and hearing can be more important than vision in some languages. 


$$
\text { Sight }>\text { Hearing }>\text { Touch }>\begin{aligned}
& \text { Smell } \\
& \text { Taste }
\end{aligned}
$$

Figure 3. Hierarchical order of perception

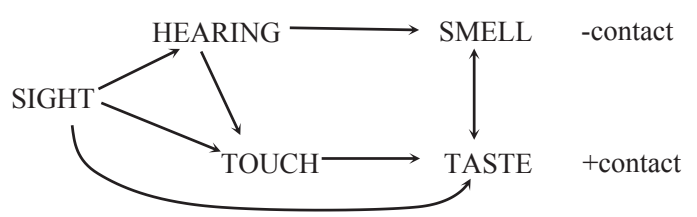

Figure 4. Semantic extensions in perceptual modalities (Viberg 1984: 147)

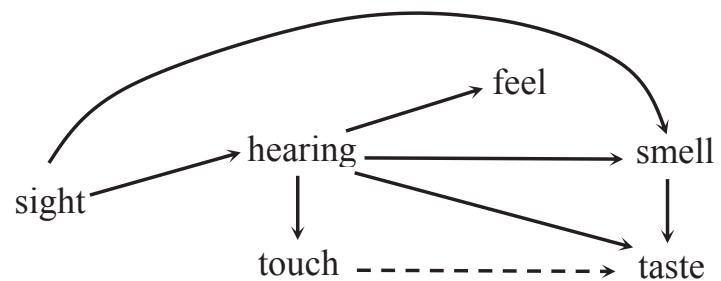

Figure 5. Semantic extensions across perceptual modalities in Australian languages (Evans and Wilkinson 2000: 560)

The importance of perceptions other than vision emerged, as suggested by Aikhenvald (p.c.) and Thanassoula (p.c.), through realisation of speakers' religious belief and importance of shaman and other religious people in society, i.e. shamans are thought to possess various skills and powers, including seeing ghosts and sprits. This visual ability forms a sharp division between religious people and lay people in the society. This division is seen in their speech, and a verb of vision is avoided by lay people, since they are aware of the lack of ability to see ghost. Religion-related perceptions involve vision, audition and olfaction, but gustation and somatosensation are not involved. Considering the hierarchical order of perception in Figure 3, the lack of touch and the presence of smell is a puzzle. 


\section{Somatosensation, topography, climate and metaphor}

Apart from religion, living environment (topography, climate, etc.) is known to influence the language, and it is perhaps the best known in various discussions under linguistic relativity, first brought to light by earlier anthropologists such as Boas, Sapire and Whorf. A notable example is words for snow in Yupik Eskimo, e.g. aput 'snow on the ground', qana 'falling snow' (Boas 1911, cf. also Regier, Carstensen and Kemp 2016). The underlying idea is that categorising objects depends on interests or needs of speakers, and environments including climates and temperatures force people to be concerned with certain objects or concepts in life. In relation to the snow examples, Whorf (1956) presented a case of Nahuatl (Uto-Aztecan), which has the identical word for 'ice' and 'cold'. There are indeed counterarguments to relativity, but this can be extended to various other aspects of hour daily life, and various linguistic features are examined, including visual lightness (Baddeley \&Attewell 2009); body parts (Witkowski \& Brown 1985, Wierzbicka 2007); topographical features of the physical environment itself (Spire 1912); linguistic tones, ratio of sonorant to obstruent segments (Everett, Blasi \& Roberts 2015; Everett 2017; Maddieson\& Coupé 2016). For instance, as Maddieson\& Coupé (2016: 10) claim, "languages spoken in areas with higher annual precipitation and greater tree cover demonstrate a lower reliance on the use of consonants in their sound patterns," demonstrating a positive association of language with the speakers' living environment.

All the cases of metaphor of cognition discussed so far involve perceptions, and it is possible to argue that another perception, somatosensation, can be found in this metaphor. A Finnish verb käsittää 'understand', as exemplified in (6), is derived from a noun käsi 'hand', which can be considered as a dead metaphor of knowledge is somatosensation. Its original meaning was 'handle, get hold of', and its metaphorisation might have been triggered by Swedish influence in a bilingual communication during the $19^{\text {th }}$ century, i.e. gripa, begripa 'get hold of' could be the base for metaphorisation in Finnish. The use of hand as its source may suggest that this metaphor is based on feeling. As mentioned earlier, body parts are known to differ according to climates in some languages, particularly a hand is differentiated from an arm in a colder climate. In case of Finnish, käsi 'hand' and käsivarsi 'arm' are two different words, although they are historically related. 


\begin{abstract}
Finnish
(6)

$\begin{array}{llllll}\text { En voi käsittää, miksi teit noin } & \\ \text { NEG can understand why do.2SG.PST that } & \end{array}$

'I can't understand why you did that.'

If this proves to be the case of somatosensation used in metaphor of cognition, a possible force behind the metaphorisation is climate, i.e. a colder climate may force people pay attention to sensory feeling through hand or finger, as overbed in naming the body parts. Thus, the topography and climate-related factors can influence the metaphorisation. The Finnish example also explains the hierarchical order shown in Figure 3, covering the range of perceptions from sight to smell. It suggests that various social and geographical factors can create metaphor of cognition, and put a question on universality of some metaphors. Once typological variations can be taken into consideration, knowledge can be vision, hearing, smell or touch.
\end{abstract}

\title{
5. Summary
}

This paper has investigated a possibility of metaphor of cognition based on somatosensation. Conceptual metaphor has been considered widespread in different parts of the world and different language families, but what is commonly thought as universal, in this case KNOWLEDGE IS VISION metaphor, can be language-specific, and culture or topography can be an important factor in influencing the variation. Languages in combination with less-studied features such as topography and climate, therefore, often reveal a new pattern in usage or structure, and interdisciplinary approaches can help us to explain how language works.

This type of research has not met a range of typological linguistic data, but there will be further findings. Furthermore, diverse morphology in human anatomy can also add to the list of features for comparison. It has been claimed that the shape of front teeth and nose can be affected by climate, and those who live in a cold climate tend to have a slightly u-shaped front teeth and a short, flat nose. These pieces of information can enrich our understanding of modern languages. 


\section{References}

Baddeley, R. \& D. Attewell 2009. 'The relationship between language and the environment: information theory shows why we have only three lightness terms.' Psychological Science 20 (9): 1100-1107.

Dahl, Ø. (1995). When the future comes from behind: Malagasy and other time concepts and some consequences for communication. International Journal of Intercultural Relations, 19, 197-209.

Evans, N. \& D. Wilkins 2000. 'In the mind's ear: The semantic extensions of perception verbs in Australian languages.' Language 76: 546-592.

Everett, C. 2017. 'Language in drier climates use fewer vowels.' Frontiers in Psychology 8. DOI: 10.3389/fpsyg.2017.01285

Everett, C., D. E. Blasi \& S. G. Roberts 2015. 'Climate, vocal folds, and tonal languages: Connecting the physiological and geographic dots.' PNAS 112 (5): 1322-1327.

Heine, B. and T. Kuteva 2002. World Lexicon of Grammaticalization. Cambridge: Cambridge University Press.

Klein, H. M. (1987). The future precedes the past: Time in Toba. Word, 38, 173-185.

Lakoff, G. (1993). 'The contemporary theory of metaphor.' In Ortony, A. (ed.) Metaphor and Thought (2nd ed.). Cambridge: Cambridge University Press, 202-251.

MacArthur, F., T. Krennmayr\& J. Littlemore 2015. 'How Basic Is "UNDERSTANDING IS SEEING" When Reasoning About Knowledge? Asymmetric Uses of Sight Metaphors in Office Hours Consultations in English as Academic Lingua Franca.' Metaphor and Symbol30 (3): 184-217.

Maddieson, I. \& Ch. Coupé 2016. 'Human spoken language diversity and the acoustic adaptation hypothesis.' Proceedings of Meetings on Acoustics 25, 1-14.

Núñeza, R. E. \& E. Sweetser 2006. 'With the future behind them: Convergent evidence from Aymara language and gesture in the crosslinguistic comparison of spatial construals of time.' Cognitive Science 30, 401-450.

Regier, T., A. Carstensen \& C. Kemp 2016. 'Languages Support Efficient Communication about the Environment: Words for Snow Revisited.' PLoS ONE 11(4): e0151138.

Sapire, E. 1912. 'Language and environment.' American Anthropologist 14: 226242.

Thanassoula, M. 2013. 'Perception in Lussesee (Bantu, J10).' In Aikhenvald, A. \& A. Storch (eds.) Perception and Cognition in Language and Culture. Leiden: Brill, 251-270.

Thanasoula, M. 2016. Towards a Grammar of the Senses: Perception in Lushese. Cologne: KUPS. 
Thornton, A. (1987). Maori Oral Literature as Seen by a Classicist. Dunedin, New Zealand: University of Otago Press.

Wierzbicka, A. 2007. 'Bodies and their parts: An NSM approach to semantic typology.' Language Sciences 29 (1): 14-65.

Whorf, B. L. 1956. Science and linguistics. In Carroll, J. B. (ed.) Language, Thought, and Reality: Selected Writings of Benjamin Lee Whorf. Cambridge (Mass): MIT Press, 207-219.

Witkowski, S. R. \& C. H. Brown 1985. 'Climate, clothing, and body-part nomenclature.' Ethnology 24, 197-214.

Junichi Toyota

\section{Sažetak \\ KULTURA I OKRUŽENJE U JEZIKU: MOGUĆE VARIJACIJE U SLUČAJU METAFORE}

Rad se bavi metaforama kognicije koje su zasnovane na senzornim glagolima dodira. Među pet osnovnih čula, glavni izvor metafora koje se odnose na znanje i razumevanje je vid. Drugi tip čula koji se koristi u ovim metaforama je sluh, posebno u jezicima koji se govore u određenim regijama, kao što su Australija, Papua Nova Gvineja, istočna Afrika. Korištenje sluha u ovim metaforama je rezultat uticaja religije, u smislu da je vid rezervisan za nadarene pojedince, a da se običan narod mora oslanjati na neke druge izvore. Slučaj somatosenzacije možda ne uključuje uticaje kulture, ali su u ovom slučaju od velikog značaja topografija i klima. Konkretno je u pitanju finski jezik, koji je razvio kognitivni glagol zasnovan na reči za ruku - käsi.

Ključne reči: metafora kognicije, topografija, klima, delovi tela 